2. Калякін С.О. Про лінійне ініціювання зарядів вибухових речовин [Текст] / С.О. Калякін, В.С. Прокопенко // Вісник Кременчуцького національного університету ім. Михайла Остроградського. - Кременчуг: КНУ, 2013. - Вип. 1/2013(11).- С.41-46. - (Серия «теоретичні й експериментальні дослідження процесів руйнування гірських порід вибухом»).

3. Добрынин, И.А. Обоснование параметров промежуточных детонаторов в скважинных зарядах для повышения эффективности дробления горных пород [Текст]: автореф. дис.... к.т.н: 03.06.2010 / Добрынин Иван Александрович; Институт проблем комплексного освоения недр РАН. - М., 2010. - 19 с.

4. Орлова, Е.Ю. Химия и технология бризантных взрывчатых веществ [Текст] / Ю.Ю. Орлова. - М.: Химия, 1981. - 312 с.

5. Дубнов, Л.В., Промышленные взрывчатые вещества [Текст]: 3-е изд. / Л.В. Дубнов, Н.С. Бахаревич, А.И. Романов. - М. «Недра», 1988. - 358 с.

Статья поступила в редакичию20.01.2017p.

УДК 651.82.681.324

DOI: $10.20535 / 2079-5688.2017 .32 .92451$

Д.В. Вінівітін, інженер (ПрАТ «Полтавський ГЗК»)

ПРАВИЛА ФОРМУВАННЯ ТЕХНОЛОГІЧНИХ ДІЛЯНОК ДЛЯ УПРАВЛІННЯ ВАНТАЖНО-ТРАНСПОРТНИМ КОМПЛЕКСОМ КАР'ЄРУ НА ІНТЕРВАЛІ ОПЕРАТИВНОГО ПЛАНУВАННЯ

D.V. Vinivitin (Ferrexpo Poltava Mining)

\title{
RULES FOR FORMATION OF TECHNOLOGICAL SITES TO MANAGE MINE LOADING-TRANSPORT COMPLEX ON THE INTERVAL OF OPERATIVE PLANNING
}

Розглянуті ситуації несумісності обмежень моделі лінійного програмування оперативного планування роботи кар'єру. Пропонується виокремити технологічні ділянки на кар'єрі, в рамках яких змінювати можливі продуктивності вантажної та приймальної ланок кар'єру.

Ключові слова: вантажно-транспортний комплекс залізорудного кар'єру; автоматизачія оперативного планування; подолання несумісності обмежень моделі; структуризачія технологічної ситуачіï.

Рассмотрень ситуации несовместности решения ограничений модели линейного программирования оперативного планирования работы карьера. Предлагается выделить технологические участки на карьере, в рамках которых изменять возможные производительности погрузочного и приемного звеньев карьера.

Ключевые слова: погрузочно-транспортный комплекс железорудного карьера; автоматизация оперативного планирования; преодоление несовместности ограничений модели; структуризация технологической ситуации. 
The situations of incompability decision of limitations of the model of linear programming of the operative planning of the work of the open pit are considered. It is suggested that technological areas on the open pit will be distiguished, within the spere of them change all possible productivities loading and receiving links of the open pit.

Keywords: a loading-transport complex of iron-ore open pit; automation of the operative planning; overcoming of incompability of the limitations of the model; partitioning of technological situation.

Актуальність роботи. Складність управління роботою кар'єру полягає у стохастичному характері протікання технологічних процесів видобутку та транспортування гірничої маси, невизначеності природних умов залягання гірничих порід. Тому сучасні системи автоматизованого управління повинні мати у своєму розпорядженні не лише можливості формування планів роботи обладнання, але і повинні оснащуватись функціями аналізу поточних гірничотехнологічних ситуацій, що склались на кар'єрі.

Мета роботи. Метою роботи $є$ дослідити можливість виокремлення технологічних ділянок на кар'єрі, в рамках яких можна змінювати продуктивності вантажної та приймальної ланок кар'єру при оперативному плануванні роботи кар'єру.

Постановка задачі досліджень. Головною задачею оперативного планування роботи кар'єру $є$ визначення кількості гірничої маси, що перевозиться від екскаваторів до пунктів розвантаження, для виконання плану за кількісними та якісними характеристиками шихти [1].

Ця задача може розв'язуватись на різних часових інтервалах [2]. За основу приймається необхідність виконання місячної програми гірничих робіт, для підготовки та затвердження якої потрібне врахування та обробка великих обсягів різноманітних інформаційних потоків $[1,2]$. Із цих міркувань випливає, що місячна програма має доволі узагальнений вигляд, вона не надто деталізується, а лише визначає, які ділянки кар'єру треба відробити, щоб виконати план (на місяць) за декількома аспектами (технологічними, економічними, технічними). Звичайно, коли виконується планування місячних об'ємів на екскаваторах, то ведеться приблизний розрахунок як об'ємів, які від них будуть перевозитись, так і якісних параметрів шихти, яку отримають на входах дробарно-збагачувального комплексу. Лише після того, як об'єми набрані, виконують перерозподіл об’ємів від екскаваторів на пункти розвантаження. На цьому етапі доцільне застосування моделей оперативного планування.

Аналіз досліджень та публікацій. Структура моделей оперативного планування, що пропонуються дослідниками до застосування, має достатньо різноманітний характер. Багато моделей носять лінійний характер i розв'язуються внаслідок цього за допомогою симплекс-методу лінійного програмування. Іноді застосовують більш складні критерії, що ускладнюється застосуванням дробово-лінійного, стохастичного або навіть динамічного програмування [3-5]. 
Найпростіша модель обумовлена навіть не досконалим знанням законів гірничої науки, а емпіричністю та великим досвідом управління роботою вантажно-транспортного обладнання. Вона має в якості критерію мінімум транспортних витрат на перевезення гірничої маси від екскаваторів до пунктів розвантаження

$$
F_{1}=\sum_{i=1}^{n} \sum_{j=1}^{m} c_{i j} \cdot P_{i j} \Rightarrow \min ,
$$

та низку обмежень гірничо-технологічного характеру, які добре формалізуються та враховують:

1) обмеження $A_{n \pi j} \leq \sum_{i=1}^{n} P_{i j} \leq A_{n n j}+\Delta A_{j}$ за об'ємом шихти, що надходить на пункт розвантаження;

2) обмеження $\alpha_{n j}-\Delta \alpha_{j} \leq \frac{\sum_{i=1}^{n} P_{i j} \cdot \alpha_{i}}{\sum_{i=1}^{n} P_{i j}} \leq \alpha_{n n j}+\Delta \alpha_{j}$ за вмістом корисного компонента в шихті;

3) обмеження $\sum_{i=1}^{n} P_{i j}^{\prime}: \sum_{i=1}^{n} P_{i j}^{\prime \prime}: \sum_{i=1}^{n} P_{i j}^{\prime \prime \prime}=T_{j}: S_{j}: L_{j}$ за співвідношенням в шихті різних сортів руд по збагачуваності;

4) обмеження $Q_{i \min } \leq \sum_{j=1}^{m} P_{i j}+V_{i} \leq Q_{i \max }$ за об'ємом видобутку кожного екскаватора; ділянки,

5) обмеження $P_{i j} \leq P_{i j}^{\max }-$ за об’ємом видобутку з кожної виймальної

де $i$ - індекс нумерації екскаваторів, $i=1 . . n ; j$ - індекс нумерації пунктів розвантаження, $j=1 . . m ; c_{i j}-$ вартість транспортування 1 т руди від i-го екскаватора до ј-го пункту розвантаження, грн.; $c_{i j}=c \cdot l_{i j}$; - питома вартість транспортування 1 т руди на 1 км, грн./т км; $l_{i j}$ відстань від і-го екскаватора до j-го пункту розвантаження; $\mathrm{P}_{\mathrm{ij}}$ - керована величина - обсяг руди, який перевозиться від і-го екскаватора до ј-го пункту розвантаження; $\alpha_{i}-$ вміст корисного компонента в руді, що відвантажує і-й екскаватор; $\alpha_{\text {плj }}$ потрібна якість шихти, що сформується на ј-й збагачувальній фабриці; $P_{i j}^{\max }$ - запас руди; $\mathrm{A}_{\text {плј }}$ об'єм гірничої маси, що надходить на ј-ий пункт розвантаження; $\Delta \mathrm{A}_{\mathrm{j}}-$ можливе відхилення об'ємних показників руди, що повинна надійти на ј-й

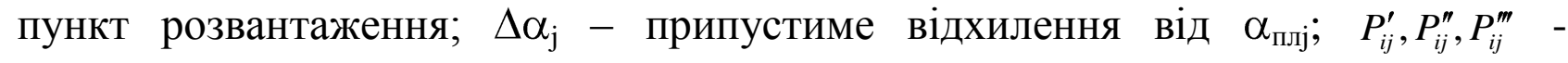
відповідно обсяги важко-, середньо- та легкозбагачувальних руд, що підлягають вийманню і-м екскаватором та поставляються на ј-у збагачувальну фабрику; $\mathrm{T}_{\mathrm{j}}, \mathrm{S}_{\mathrm{j}}, \mathrm{L}_{\mathrm{j}}$ - частки важко-, середньо- та легкозбагачуваних руд в процентному відношенні, що відповідають вимогам ј-ї збагачувальної фабрики; $\mathrm{Q}_{\text {imin }}, \mathrm{Q}_{\mathrm{imax}}$ - відповідно мінімальна та максимальна продуктивність екскаватора 
в конкретному забої; $\mathrm{V}_{\mathrm{i}}$ - обсяг скального розкриття, який потрапив в контур видобуткових робіт і-го екскаватора.

Результати досліджень. Вищезазначена модель та закономірності прості та логічні, добре формалізують задачу оперативного планування, мають достатньо розвинені методи розв'язання, реалізовані у декількох програмних продуктах. Звичайно, задачу можна ускладнювати і багатокритеріальністю, i врахуванням стохастичності параметрів $\mathrm{Q}_{\mathrm{i}}$ та $\alpha_{\mathrm{i}}$, це дасть дещо інше рішення, але це не дуже істотно вплине на характер розв'язання та інтерпретації результату.

3 іншого боку, будь-яку математичну модель потрібно коректно адаптувати для реальних виробничих умов. При цьому виникають відразу декілька питань, на які важко знайти однозначну відповідь. В основному вони стосуються підготовки початкових даних, які лежать в основі розрахунків. Параметри $c, l, \alpha, T, S, L, V, P_{i j}^{\max }$ можуть бути розраховані або задані 3 достатньою точністю, але знаходження параметрів $Q$ та $A_{n л}$ може бути окремою задачею, причому не дуже простою. Звичайно, на кожному кар'єрі існують норми виробки екскаваторів для різних гірничих умов, які грунтуються на обробці багаторічного статистичного матеріалу. Проте ніхто не вважає їх добре вірогідними для моделювання майбутніх процесів, їх можна приймати як орієнтовні. Крім того, величину $Q$ треба вважати ще й обумовленою роботою транспортної ланки, адже продуктивність екскаваторів визначається продуктивністю транспортної ланки

$$
Q_{j(n)}=\sum_{j=1}^{n} P_{j(n)}^{(n n)},
$$

i iз збільшенням значень $n$ збільшується до певної величини, а потім залишається сталою (тут $P_{j(n)}^{(\mathrm{s})}-$ продуктивність автосамоскиду).

Тому фактично величина продуктивності екскаватора це величина, якою можна варіювати для врахування певних гірничих умов, що склались на кар'єрі у певний період часу.

В якості прикладу розглянемо наступну ситуацію, для якої треба скласти план вантажоперевезень розкриття. Можуть працювати 12 екскаваторів на 9 розвантажувальних пунктів.

Дані про екскаватори наведені у таблиці 1, а про пункти розвантаження у табл. 2.

Таблиця 1

Дані для планування роботи екскаваторів на 09.10.2016

\begin{tabular}{|c|c|c|c|}
\hline № екскаватора & $\begin{array}{c}\text { Тип гірничої } \\
\text { маси }\end{array}$ & $\begin{array}{c}\text { Максимальна } \\
\text { продуктивність, } \\
\text { тис.м³/добу }\end{array}$ & $\begin{array}{c}\text { Можливі пункти } \\
\text { розвантажень }\end{array}$ \\
\hline 11 & Граніти & 6,47 & 148 \\
\hline 41 & Суміш скали & 16,35 & $148, \mathrm{Cx}, 69,8,90$ \\
\hline
\end{tabular}




\begin{tabular}{|c|c|c|c|}
\hline № екскаватора & $\begin{array}{c}\text { Тип гірничої } \\
\text { маси }\end{array}$ & $\begin{array}{c}\text { Максимальна } \\
\text { продуктивність, } \\
\text { тис.м³/добу }\end{array}$ & $\begin{array}{c}\text { Можливі пункти } \\
\text { розвантажень }\end{array}$ \\
\hline 72 & Граніти & 3,75 & 148 \\
\hline 47 & Кварцити & 7,5 & 148 \\
\hline 52 & Граніти & 3,07 & 148 \\
\hline 40 & Граніти & 12,27 & $22,7,85$ \\
\hline 23 & Кварцити & 3,41 & $148, \mathrm{Cx}, 69,8,90$ \\
\hline 43 & Кварцити & 2,73 & $148, \mathrm{Cx}, 69,8,90$ \\
\hline 45 & Суміш скали & 8,86 & $148, \mathrm{Cx}, 69,8,90$ \\
\hline 44 & Кварцити & 7,67 & $148, \mathrm{Cx}, 69,8,90$ \\
\hline 35 & Кварцити & 4,77 & $148, \mathrm{Cx}, 69,8,90$ \\
\hline 12 & Глина & 2,04 & $148,3 a x$ \\
\hline \multicolumn{2}{|r|}{ Усього } & 78,89 & \\
\hline
\end{tabular}

Таблиця 2

Дані для планування роботи екскаваторів на 09.10.2016

\begin{tabular}{|c|c|c|c|}
\hline $\begin{array}{c}\text { Назва } \\
\text { пункту } \\
\text { розванта- } \\
\text { ження }\end{array}$ & $\begin{array}{c}\text { Тип } \\
\text { гірничої } \\
\text { маси }\end{array}$ & $\begin{array}{c}\text { Приймальна } \\
\text { здатність } \\
\text { (максимальна) } \\
\text { пункту, тис.м }{ }^{3} / \text { добу }\end{array}$ & $\begin{array}{l}\text { Екскаватори, що можуть } \\
\text { вантажити гірничу масу }\end{array}$ \\
\hline 69 & Скала & 1,93 & $41,23,43,45,44,35$ \\
\hline 8 & Скала & 3,22 & $41,23,43,45,44,35$ \\
\hline 90 & Скала & 3,22 & $41,23,43,45,44,35$ \\
\hline 22 & Скала & 3,54 & 40 \\
\hline 85 & Скала & 3,87 & 40 \\
\hline 7 & Скала & 4,19 & 40 \\
\hline 148 & Розкриття & 15,48 & $11,41,72,47,52,23,43,45,44,35,12$ \\
\hline $\mathrm{Cx}$ & Скала & 20,77 & $23,43,45,44,35$ \\
\hline $3 a x$ & Наноси & 21,93 & 12 \\
\hline & Усього & 78,15 & \\
\hline
\end{tabular}

Більш наочно цю ситуацію можна представити графічно (рис.1). 

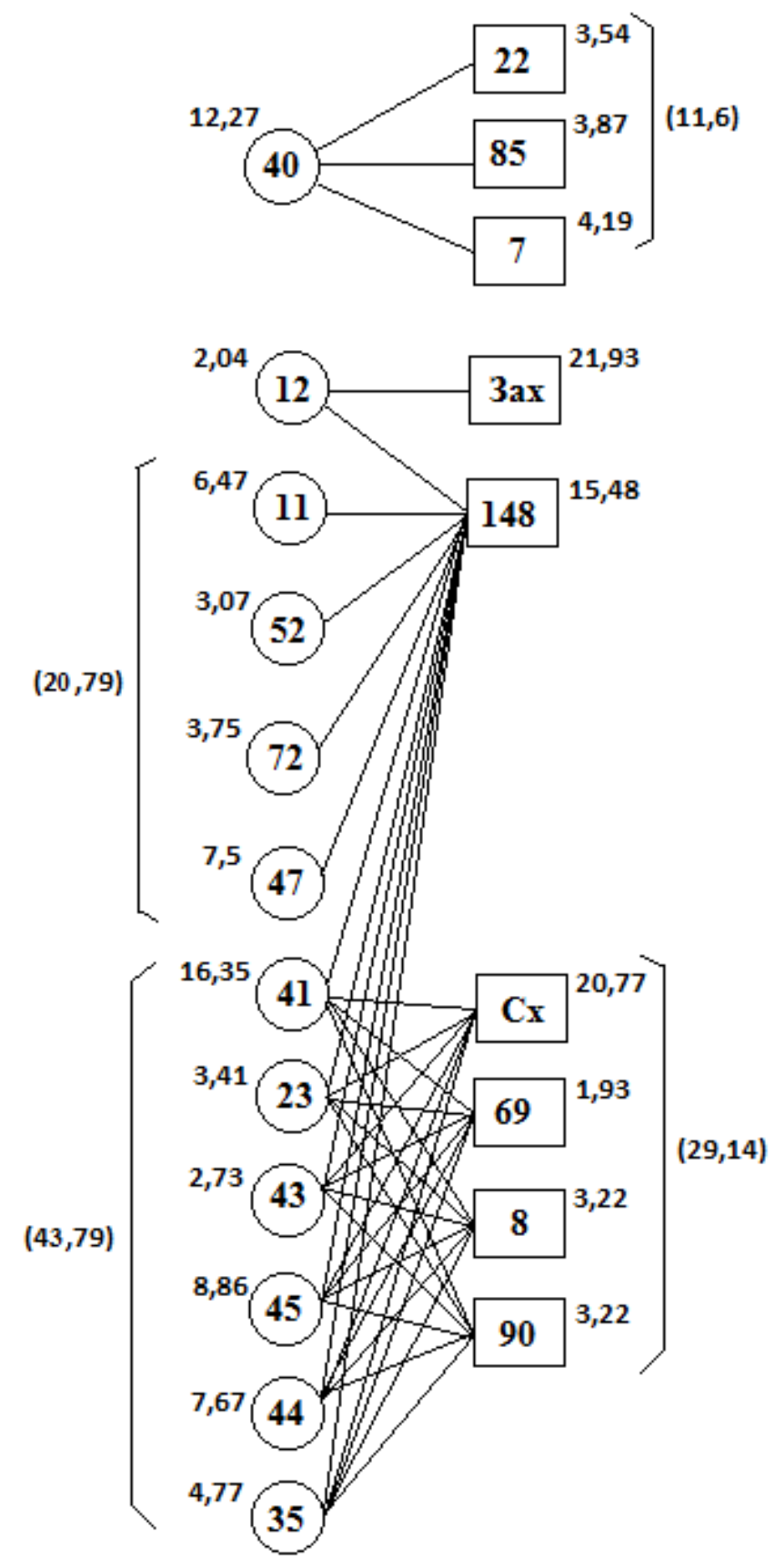

Рис.1. Початкові дані для визначення вантажопотоків

На рис.1 кружечками показані екскаватори, прямокутниками - пункти розвантаження, поруч 3 фігурами вказані максимальні продуктивності екскаваторів або максимальні приймальні здатності пунктів розвантаження.

Із п'яти вказаних у моделі обмежень в даному випадку актуальними будуть перше і четверте, які утворять сумарно 12+9=21 подвійні нерівності. При цьому перші 12 нерівності відповідають обмеженням 3 продуктивності екскаваторів:

$$
\mathrm{Q}_{40} \leq \mathrm{P}_{40-22}+\mathrm{P}_{40-85}+\mathrm{P}_{40-7} \leq 12,27 \text {; }
$$




$$
\begin{gathered}
\mathrm{Q}_{12} \leq \mathrm{P}_{12-3 a x}+\mathrm{P}_{12-148} \leq 2,04 ; \\
\mathrm{Q}_{11} \leq \mathrm{P}_{11-148} \leq 6,47 ; \\
\mathrm{Q}_{52} \leq \mathrm{P}_{52-148} \leq 3,07 ; \\
\mathrm{Q}_{72} \leq \mathrm{P}_{72-148} \leq 3,75 ; \\
\mathrm{Q}_{47} \leq \mathrm{P}_{47-148} \leq 7,5 ; \\
\mathrm{Q}_{41} \leq \mathrm{P}_{41-\mathrm{Cx}}+\mathrm{P}_{41-148}+\mathrm{P}_{41-69}+\mathrm{P}_{41-8}+\mathrm{P}_{41-90} \leq 16,35 ; \\
\mathrm{Q}_{23} \leq \mathrm{P}_{23-\mathrm{Cx}}+\mathrm{P}_{23-148}+\mathrm{P}_{23-69}+\mathrm{P}_{23-8}+\mathrm{P}_{23-90} \leq 3,41 ; \\
\mathrm{Q}_{43} \leq \mathrm{P}_{43-\mathrm{Cx}}+\mathrm{P}_{43-148}+\mathrm{P}_{43-69}+\mathrm{P}_{43-8}+\mathrm{P}_{43-90} \leq 2,73 ; \\
\mathrm{Q}_{45} \leq \mathrm{P}_{45-\mathrm{Cx}}+\mathrm{P}_{45-148}+\mathrm{P}_{45-69}+\mathrm{P}_{45-8}+\mathrm{P}_{45-90} \leq 8,86 ; \\
\mathrm{Q}_{44} \leq \mathrm{P}_{44-\mathrm{Cx}}+\mathrm{P}_{44-148}+\mathrm{P}_{44-69}+\mathrm{P}_{44-8}+\mathrm{P}_{44-90} \leq 7,67 ; \\
\mathrm{Q}_{35} \leq \mathrm{P}_{35-\mathrm{Cx}}+\mathrm{P}_{35-148}+\mathrm{P}_{35-69}+\mathrm{P}_{35-8}+\mathrm{P}_{35-90} \leq 4,77,
\end{gathered}
$$

a інші 9 обмежень обумовлені приймальними здатностями пунктів розвантаження:

$$
\begin{gathered}
\mathrm{A}_{22} \leq \mathrm{P}_{40-22} \leq 3,54 ; \\
\mathrm{A}_{85} \leq \mathrm{P}_{40-85} \leq 3,87 ; \\
\mathrm{A}_{7} \leq \mathrm{P}_{40-7} \leq 4,19 ; \\
\mathrm{A}_{3 \mathrm{xax}} \leq \mathrm{P}_{12-3 \mathrm{ax}} \leq 21,93 ; \\
\mathrm{A}_{148} \leq \mathrm{P}_{12-148}+\mathrm{P}_{11-148}+\mathrm{P}_{52-148}+\mathrm{P}_{72-148}+\mathrm{P}_{47-148}+\mathrm{P}_{41-148}+\mathrm{P}_{23-148}+\mathrm{P}_{43-148}+\mathrm{P}_{45-148}+\mathrm{P}_{44-148}+\mathrm{P}_{35-} \\
148 \leq 15,48 \\
\mathrm{~A}_{\mathrm{Cx}} \leq \mathrm{P}_{41-\mathrm{Cx}}+\mathrm{P}_{23-\mathrm{Cx}}+\mathrm{P}_{43-\mathrm{Cx}}+\mathrm{P}_{45-\mathrm{Cx}}+\mathrm{P}_{44-\mathrm{Cx}}+\mathrm{P}_{35-\mathrm{Cx}} \leq 20,77 ; \\
\mathrm{A}_{69} \leq \mathrm{P}_{41-69}+\mathrm{P}_{23-69}+\mathrm{P}_{43-69}+\mathrm{P}_{45-69}+\mathrm{P}_{44-69}+\mathrm{P}_{35-69} \leq 1,93 ; \\
\mathrm{A}_{8} \leq \mathrm{P}_{41-8}+\mathrm{P}_{23-8}+\mathrm{P}_{43-8}+\mathrm{P}_{45-8}+\mathrm{P}_{44-8}+\mathrm{P}_{35-8} \leq 3,22 ; \\
\mathrm{A}_{90} \leq \mathrm{P}_{41-90}+\mathrm{P}_{23-90}+\mathrm{P}_{43-90}+\mathrm{P}_{45-90}+\mathrm{P}_{44-90}+\mathrm{P}_{35-90} \leq 3,22 .
\end{gathered}
$$

Значення $Q$ та $A$ можуть приймати значення від 0 до своїх максимальних значень. Якщо усі $Q$ та $A$ прийняти рівними 0 , то отримаємо тривіальне рішення, коли усі $\mathrm{P}_{\mathrm{ij}}=0$, що не має фактичного сенсу. Тому якісь значення $Q$ i $A$ повинні бути відмінними від 0 і на етапі підготовки вихідних даних задачі оперативного планування потрібно визначити коректні величини продуктивності екскаваторів та приймальних здатностей пунктів розвантаження.

Дуже часто виникає ситуація умовного дефіциту, коли один з елементів вантажоперевезень (екскаватори або пункти розвантаження) не може забезпечити нормальне функціонування усього вантажно-приймального комплексу, тобто $\Sigma \mathrm{Q} \neq \Sigma \mathrm{A}$. Тоді елемент з меншим значенням продуктивності в лівій частині нерівності має 0 , а з більшим - розраховується пропорційно. Тобто при $\Sigma \mathrm{Q}<\Sigma \mathrm{A} \quad$ усі $Q_{\min i}=Q_{\max } \frac{\Sigma Q}{\Sigma A}, \quad$ а якщо $\Sigma \mathrm{Q}>\Sigma \mathrm{A}, \quad$ то усі $A_{\min i}=A_{\max i} \frac{\sum A}{\Sigma Q}$.

У нашому прикладі $\Sigma \mathrm{Q}=78,89, \Sigma \mathrm{A}=78,15$, тому приймаємо

$$
\begin{gathered}
\mathrm{Q}_{40}=12,27 \cdot 78,15 / 78,89=12,15 ; \mathrm{Q}_{12}=2,04 \cdot 78,15 / 78,89=2,02 ; \\
\mathrm{Q}_{11}=6,47 \cdot 78,15 / 78,89=6,41 ; \mathrm{Q}_{52}=3,07 \cdot 78,15 / 78,89=3,04 ; \\
\mathrm{Q}_{72}=3,75 \cdot 78,15 / 78,89=3,71 ; \mathrm{Q}_{47}=7,5 \cdot 78,15 / 78,89=7,43 ; \\
\mathrm{Q}_{41}=16,35 \cdot 78,15 / 78,89=16,2 ; \mathrm{Q}_{23}=3,41 \cdot 78,15 / 78,89=3,38 ;
\end{gathered}
$$




$$
\begin{aligned}
& \mathrm{Q}_{43}=2,73 \cdot 78,15 / 78,89=2,70 ; \mathrm{Q}_{45}=8,86 \cdot 78,15 / 78,89=8,78 ; \\
& \mathrm{Q}_{44}=7,67 \cdot 78,15 / 78,89=7,60 ; \mathrm{Q}_{35}=4,77 \cdot 78,15 / 78,89=4,73 .
\end{aligned}
$$

Тоді сформувавши модель оперативного планування, спробуємо знайти вантажопотоки $\mathrm{P}_{\mathrm{ij}}$. Скористаємось для цього програмним продуктом K-MINE (розробник - Кривбасакадемінвест, Україна), який надає зручний інтерфейс для розв'язання задачі оперативного планування.

Проте, як видно для заданої гірничої ситуації, задача не має математичного розв’язання для оперативного планування (рис.2):

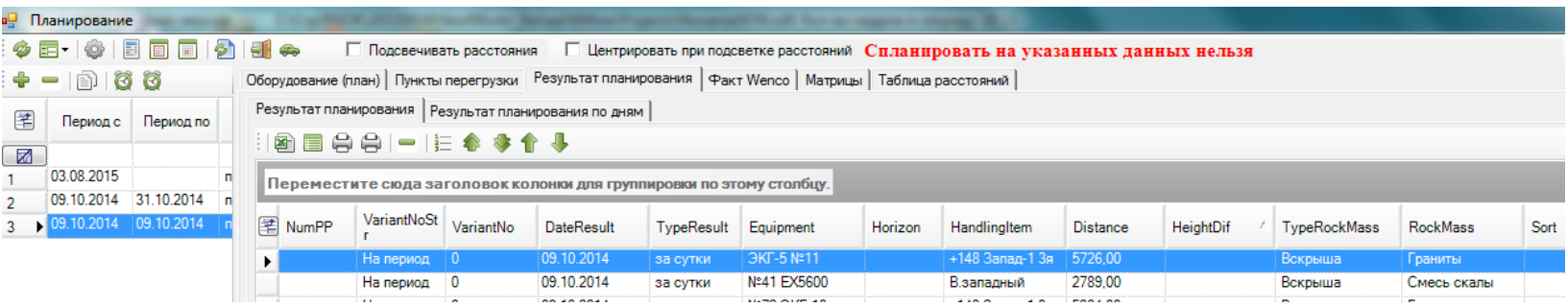

Рис. 2. Результат розв’язання

Отже, потрібно вносити корективи. Для цього проаналізуємо схему, зображену на рис.1. У всій структурі можливих вантажоперевезень виділяються чотири умовно відокремлені групи:

1. Екскаватор 40 може вантажити гірничу масу на пункти 22, 85 та 7, причому ці пункти приймають вантажі лише від цього екскаватора, і більше ні від жодного. Тобто можемо вважати, що загальна задача розподілу вантажопотоків має невелику умовно самостійну систему обмежень, сформовану екскаватором 40 та пунктами розвантаження 22, 85 та 7. Спробуємо розв’язати їі окремо.

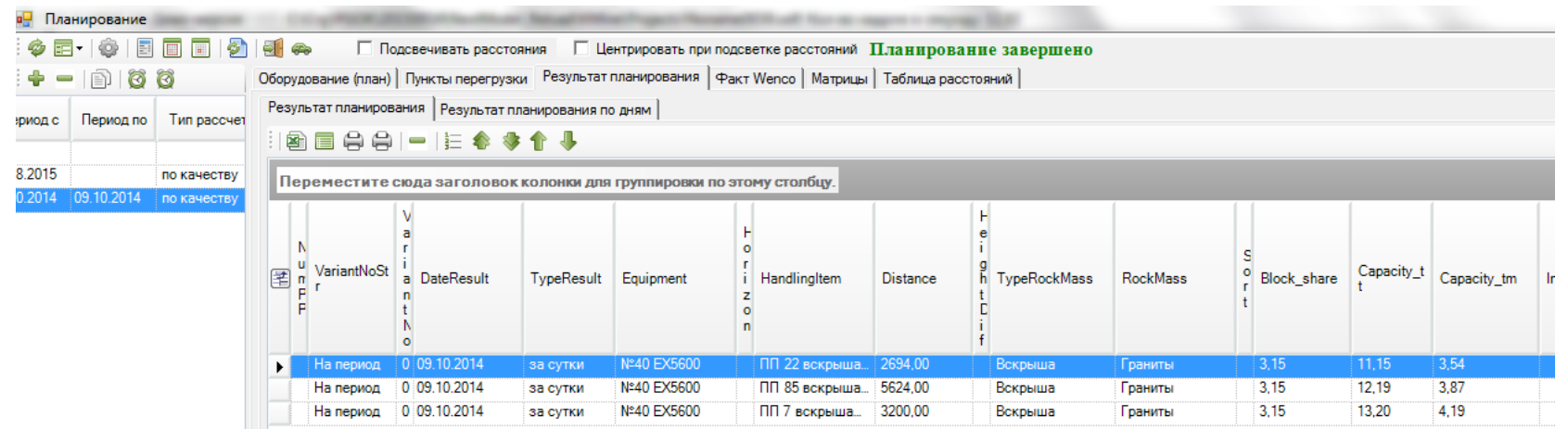

Рис. 3. Розв’язання окремої підсистеми 1

В даному випадку розв'язок зводиться до вказаних максимальних продуктивностей екскаваторів: $\mathrm{P}_{40-22}=3,54 ; \mathrm{P}_{40-85}=3,87 ; \mathrm{P}_{40-7}=4,19$.

2. Екскаватори $11,52,72,47$ можуть відвантажувати гірничу масу лише на пункт розвантаження 148, причому їхня сумарна продуктивність складає від

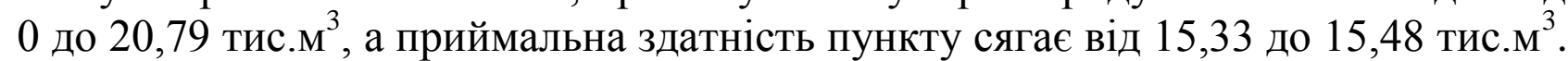
Перевіримо можливість розв’язання такої підсистеми (рис.4): 


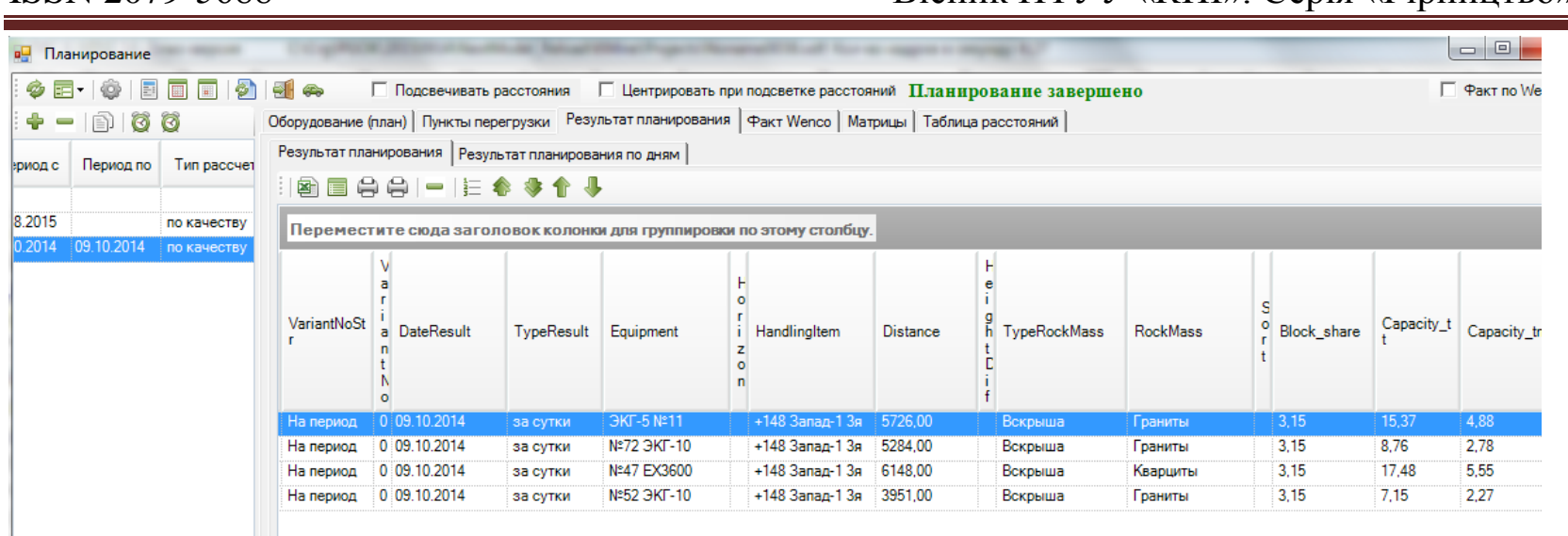

Рис. 4. Розв'язання підсистеми 2

Тут спостерігаємо певну оптимізацію розв'язку: $\mathrm{P}_{11-148}=4,88 ; \mathrm{P}_{52-148}=2,27$; $\mathrm{P}_{72-148}=2,78 ; \mathrm{P}_{47-148}=5,55$.

3. Екскаватори 41, 23, 43, 45, 44, 35 працюють на усі пункти розвантаження, крім Західного, але вважатимемо, що пункт 148 заповнюють екскаватори з п.2. Тому розглянемо ситуацію, коли дані екскаватори працюють на пункти розвантаження Східний, 69, 8, 90 (рис.5):

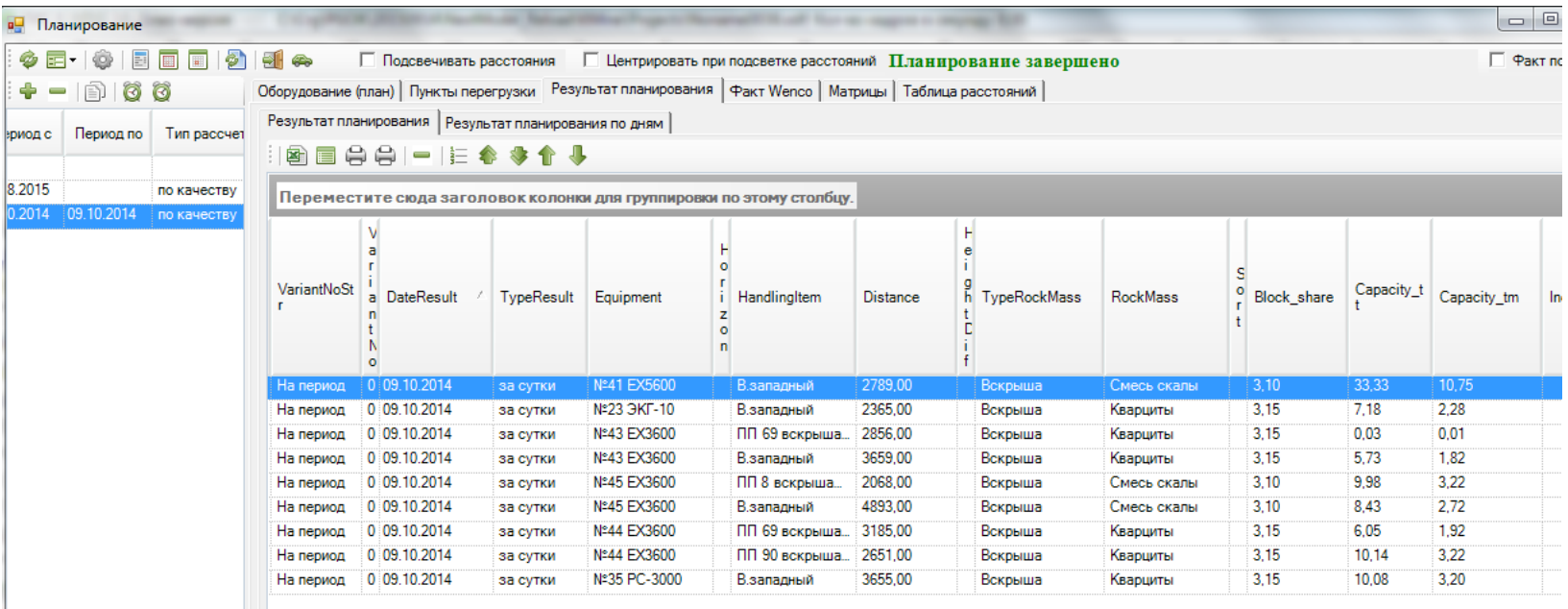

Рис. 5. Розв’язання підсистеми 3

Маємо наступне розв'язання: $\mathrm{P}_{41-\mathrm{Cx}}=10,75 ; \quad \mathrm{P}_{23-\mathrm{Cx}}=2,28 ; \quad \mathrm{P}_{43-\mathrm{Cx}}=1,82$; $\mathrm{P}_{45-8}=3,22 ; \quad \mathrm{P}_{45-\mathrm{Cx}}=2,72 ; \quad \mathrm{P}_{44-69}=1,92 ; \quad \mathrm{P}_{44-90}=3,22 ; \quad \mathrm{P}_{35-\mathrm{Cx}}=3,20 ; \quad$ усі інші вантажопотоки дорівнюють нулю.

4. Остання підгрупа точно не матиме розв'язку: екскаватор 12 може відвантажувати гірничу масу лише на пункт розвантаження Захід. Продуктивність екскаватора від 0 до 2,04, а приймальна здатність пункту від 21,72 до 21,93 , тобто екскаватор нездатний забезпечити потрібний об'єм наносів.

Але, звичайно, система планування вантажопотоків, яка претендує на автоматизованість, повинна автономно визначати такі вузькі місця гірничих ситуацій, що склались на кар'єрі, і вживати відповідних заходів.

Тому на основі проведеного аналізу позаштатної ситуації сформуємо 
наступні рекомендації, дотримання яких зменшить невизначеність оперативного планування:

При невідповідності об'ємів екскаваторів та пунктів розвантаження потрібно пропорційно змінювати мінімальну продуктивність тих суб'єктів процесу оперативного планування, які мають більшу продуктивність.

Загальну схему можливого формування вантажопотоків треба розбити на локальні умовно самостійні підсистеми. Основним фактором розбиття можна прийняти той фактор, що екскаватор може відвантажувати гірничу масу лише на один пункт розвантаження або той, що пункт розвантаження може забезпечуватись гірничою масою лише від одного екскаватора.

Слід обов'язково також виділити підсистеми, які повністю відповідають поняттю самостійності, тобто коли $\mathrm{ml}$ екскаваторів утворюють локальну систему вантажоперевезень 3 n1 пунктами розвантаження.

Розрахунок мінімальних продуктивностей слід проводити в межах кожної локальної підсистеми.

Застосуємо сформовані додаткові рекомендації до розв’язання схеми вантажоперевезень згідно рис. 1. Для цього узгоджуються вантажопотоки екскаватора 12 (від 0 до 2,04) та пункту розвантаження Східний (від 21,72 до 21,93), тобто призначаємо пункту Східний мінімальну приймальну здатність рівною 2,04 замість 21,72. Відповідно при цьому сумарна приймальна здатність пунктів розвантаження знизиться до 78, 15-21,72+2,04=58,47.

Усі інші локальні підсистеми узгоджені у відповідності до сформованих рекомендацій. Для підсистеми 2 розрахуємо мінімальні продуктивності екскаваторів:

для екскаватора $11-6,47 \cdot 15,48 / 20,79=4,82$;

для екскаватора $52-3,07 \cdot 15,48 / 20,79=2,29$;

для екскаватора $72-3,75 \cdot 15,48 / 20,79=2,79$;

для екскаватора $47-7,5 \cdot 15,48 / 20,79=5,58$.

Для підсистеми 3 також розраховуємо мінімальні продуктивності екскаваторів:

для екскаватора $41-16,35 \cdot 29,14 / 43,79=10,88$;

для екскаватора $23-3,41 \cdot 29,14 / 43,79=2,27$;

для екскаватора $43-2,73 \cdot 29,14 / 43,79=1,82$;

для екскаватора $45-8,86 \cdot 29,14 / 43,79=5,90$;

для екскаватора $44-7,67 \cdot 29,14 / 43,79=5,1$;

для екскаватора $35-4,77 \cdot 29,14 / 43,79=3,17$.

Отримуємо наступний розв'язок (рис.6): $\mathrm{P}_{40-22}=3,54 ; \mathrm{P}_{40-85}=3,87 ; \mathrm{P}_{40-7}=4,19$; $\mathrm{P}_{12-3 \mathrm{ax}}=2,04 ; \mathrm{P}_{11-148}=4,88 ; \mathrm{P}_{52-148}=2,27 ; \mathrm{P}_{72-148}=2,78 ; \mathrm{P}_{47-148}=5,55 ; \mathrm{P}_{41-C x}=15,28 ; \mathrm{P}_{41-}$ ${ }_{69}=\mathrm{P}_{41-8}=\mathrm{P}_{41-90}=0 ; \quad \mathrm{P}_{23-C x}=3,41 ; \quad \mathrm{P}_{23-69}=\mathrm{P}_{23-8}=\mathrm{P}_{23-90}=0 ; \quad \mathrm{P}_{43-C x}=0 ; \quad \mathrm{P}_{43-69}=1,60 ; \quad \mathrm{P}_{43-8}=\mathrm{P}_{43-}$ ${ }_{90}=0 ; \quad \mathrm{P}_{45-8}=2,90 ; \quad \mathrm{P}_{45-69}=\mathrm{P}_{45-C x}=\mathrm{P}_{45-90}=0 ; \quad \mathrm{P}_{44-C x}=\mathrm{P}_{44-69}=\mathrm{P}_{44-8}=1,06 ; \quad \mathrm{P}_{44-90}=2,90 ; \quad \mathrm{P}_{35-}$ $\mathrm{Cx}_{\mathrm{x}}=\mathrm{P}_{35-69}=\mathrm{P}_{35-8}=\mathrm{P}_{35-90}=0$. 


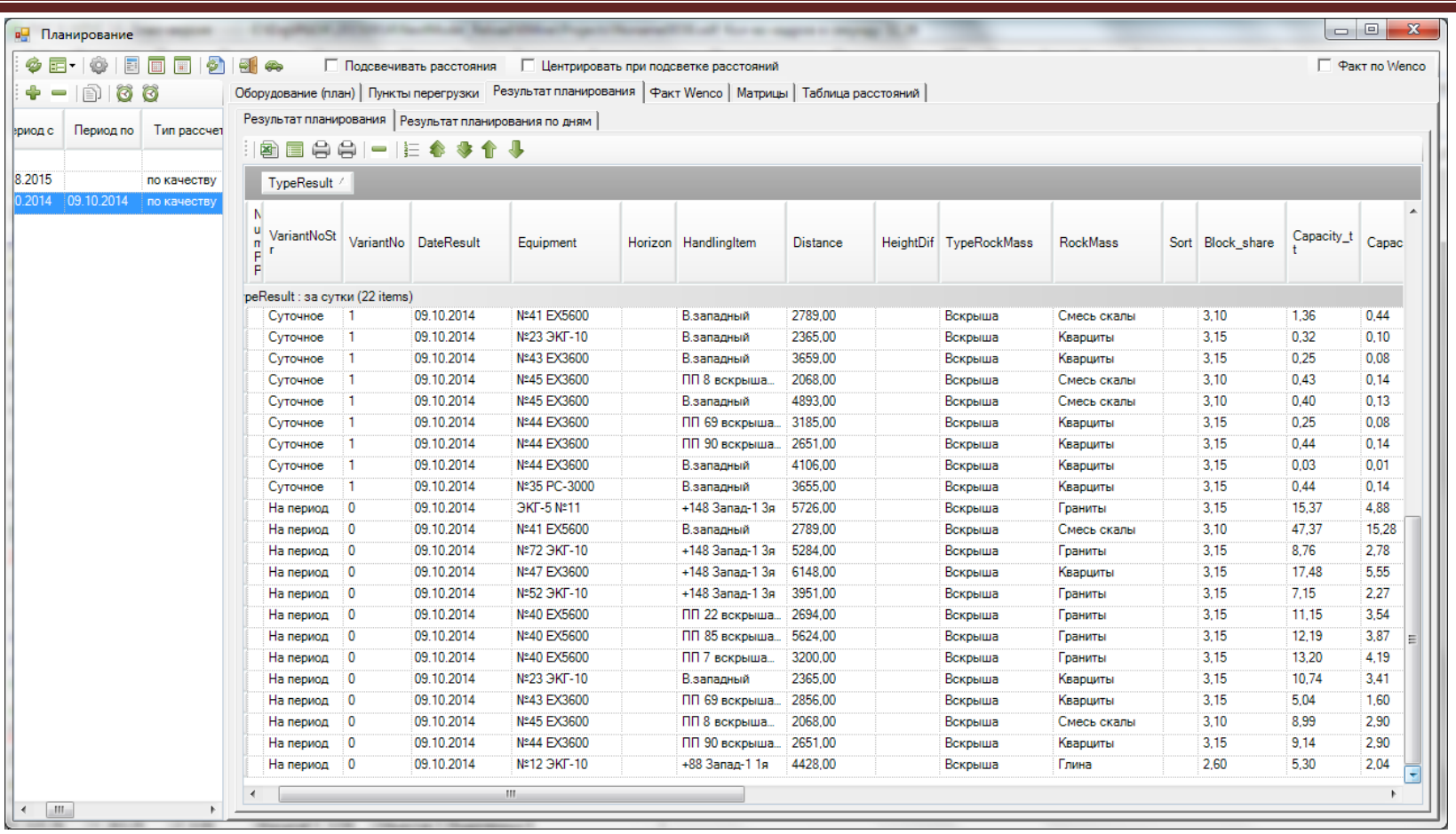

Рис. 6. Загальний розв'язок задачі оперативного планування з урахуванням наявних технологічних ділянок

\section{Висновки}

1. Моделі оперативного планування роботою вантажно-транспортного комплексу кар'єру повинні доповнюватись необхідністю розбиття на технологічні ділянки у відповідності до гірничої ситуації, що склалась. Додаткове структурування гірничотранспортної ситуації при складанні обмежень математичної моделі задачі оперативного планування дозволило досягти іiі сумісності у 54\% випадків незнаходження рішень.

2. Для запобігання незбіжності розв'язку задачі оперативного планування можна варіювати продуктивністю вантажних та приймальних елементів кар'єру в межах технологічних ділянок. При цьому можна очікувати зниження коливальності продуктивності окремих вантажних одиниць на 7-16\% та загальної продуктивності по кар'єру на 4-9\% за різними типами гірничої маси.

\section{Список використаних джерел}

1. Нападайло, В.А. Оперативное планирование и управление горным производством на карьерах [Текст] / В.А. Нападайло, В.С. Матвеев, В.В. Панченко. - М.: Недра, 1976. - 191 с.

2. Астафьев, Ю.П. Планирование и организация погрузочнотранспортных работ на карьерах [Текст] / Ю.П. Астафьев, Г.К. Полищук, Н.И. Горлов. - М.: Недра, 1986. - 168 с.

3. Капутин, Ю.Е. Информационные технологии планирования горных работ (для горных инженеров) [Текст]. - С.-Пб.: Недра, 2004. - 420 с. 
4. Диколов, С.В. Разработка системы управления автомобильным транспортом на доставке железной руды [Текст]: автореф. дис. канд. техн. / С.В. Диколов, - Москва, 1999.

5. Franklin, P.J. 1999, Integrated Resource Asset Management - A holistic approach to information technology in mining operations [Text]. Prepared for PACRIM, Bali.

Стаття надійшла до редакиії 09.02.2017p.

УДК 622.235

DOI: $10.20535 / 2079-5688.2017 .32 .93983$

О.О. Фролов, д.т.н, проф., В.З. Ващук, аспірант, В.Т. Моденко, студент, А.В. Куляпіна, студент (КПІ ім. Ігоря Сікорського)

\title{
ВСТАНОВЛЕННЯ ЗАКОНОМІРНОСТЕЙ РУЙНУВАННЯ ГІРСЬКИХ ПОРІД ВИБУХОМ СВЕРДЛОВИННИХ ЗАРЯДІВ ЗІ СПОВІЛЬНЕННЯМ
}

A.A. Frolov, V.Z. Vashchuk, V.T. Modenko, A.V. Kuliapina (Igor Sikorsky Kyiv Polytechnic Institute)

\section{ESTABLISHMENT OF THE REGULARITIES OF THE DESTROY OF ROCKS BY EXPLOSION OF BOREHOLE CHARGES WITH THE SLOWDOWN}

\begin{abstract}
Запропоновано для дослідження взаємодіі енергетичних потоків при короткосповільненому підриванні системи свердловинних зарядів визначати напружений стан гірського масиву на підставі принципу суперпозииії хвиль напружень з урахуванням рішення задачі про руйнування порід вибухом одиночного заряду. Встановлено, щзо максимальне значення об’єму руйнувань порід при наявності однієї площини оголення перебуває в однозначній залежності від інтервалу сповільнення між вибухами суміжних зарядів.
\end{abstract}

Ключові слова: вибух; скельні породи; свердловинний заряд; вибухова речовина; короткосповільнене підривання; гірський масив.

Предложено для исследования взаимодействия энергетических потоков при короткозамедленном взрывании системы скважинных зарядов определять напряженное состояние горного массива на основании принципа суперпозищии волн напряжений на основе решения задачи о разрушении пород взрывом одиночного заряда. Установлено, что максимальное значение объема разрушений пород при наличии одной плоскости обнажения находится в однозначной зависимости от интервала замедления между взрывами смежных зарядов.

Ключевые слова: взрыв; скальные породы;; скважинный заряд; взрывчатое вещество; короткозамедленное взрывание; горный массив.

Proposed for studies of the interaction of energy flows in short-delay blasting of borehole charges system to determine the stress state of the massif based on the principle of superposition of stress waves based on the solution to the problem of destruction of rocks by explosion of a single charge. It is established that the maximum value of the amount of destruction of rocks in the 